\title{
Development of a sensitive and controlled real-time RT-PCR assay for viral haemorrhagic septicaemia virus (VHSV) in marine salmonid aquaculture
}

\author{
Iveta Matejusova", Paul McKay, Alastair J. A. McBeath, Bertrand Collet, Michael Snow \\ Fisheries Research Services (FRS) Marine Laboratory, 375 Victoria Road, Aberdeen AB11 9DB, UK
}

\begin{abstract}
A survey was undertaken to determine the potential distribution of viral haemorrhagic septicaemia virus (VHSV) in marine cage-based salmonid farms in Scotland. A rapid, accurate and sensitive quantitative real-time RT-PCR (qRT-PCR) assay was developed, targeting a conserved region of the nucleoprotein $(\mathrm{N})$ gene of the virus. The qRT-PCR assay was shown to be more sensitive than the conventional VHSV RT-PCR. A validation protocol included several different virus isolates as the target and confirmed that the assay could detect all European VHSV genotypes (I, II and III). Both endogenous and exogenous controls were designed to control for integrity of template and distinguish between true VHSV positives and contamination with the positive control material. In total, the universal European VHSV qRT-PCR assay with exogenous positive control was applied to screen 2040 individual Atlantic salmon Salmo salar and 150 individual rainbow trout Oncorhynchus mykiss. No evidence of the presence of VHSV in association with either salmonid species in Scottish marine farms was detected. However, both marine Atlantic salmon and rainbow trout are still considered possible carriers of VHSV, which remains a potential threat to freshwater farming. Therefore, a continued surveillance of these species in marine environment is recommended.
\end{abstract}

KEY WORDS: Viral haemorrhagic septicaemia virus · VHSV • Atlantic salmon · Rainbow trout • Taqman · Real-time PCR · Mariculture

\section{INTRODUCTION}

Viral haemorrhagic septicaemia virus (VHSV) is a rhabdovirus which has been responsible for significant losses in European rainbow trout aquaculture since its identification in the early days of the industry (Schäperclaus 1938). Phylogenetic analyses based on different genes have identified 4 robust and readily identifiable genotypes of the virus with a geographic basis for their distribution (Snow et al. 1999, 2004, Einer-Jensen et al. 2004, 2005). Isolates belonging to Genotype IV have only been isolated in the USA and in Japan (Nishizawa et al. 2002, Elsayed et al. 2006), whereas Genotypes I, II and III are present in Europe. Viruses belonging to each of the 4 main VHSV genotypes have been shown to be endemic in the marine environment.
Indeed, within Europe, Genotypes I and II have been isolated from a wide range of host species largely restricted to the Baltic Sea, whilst Genotype III isolates have been recovered from free-living fish in the eastern Atlantic Ocean and North Sea.

All VHSV strains responsible for losses in rainbow trout aquaculture in Europe are classified within Genotype I, though this group also includes a number of isolates recovered from wild fish (Einer-Jensen et al. 2004). Those viruses from wild fish do not generally cause significant disease in experimentally infected rainbow trout (Skall et al. 2004) but share a close genetic relationship with disease-causing isolates. This evidence, coupled to the fact that VHSV does not cause disease in rainbow trout in the USA, has led to the widespread belief that the appearance of VHSV in 
the European rainbow trout industry is related to the common practice of feeding unpasteurised fish products to rainbow trout in the early days of the industry (Skall et al. 2005). Difficulties in eradicating pathogens in aquaculture have resulted in a continued disease problem within the industry. Furthermore, genetic evidence suggests that this adaptation may have occurred more recently on numerous independent occasions in marine aquaculture farms in Scandinavia, where rainbow trout may have been exposed to an endemic viral reservoir (Einer-Jensen et al. 2004). The capacity of RNA viruses such as VHSV to evolve rapidly is well known (Knipe et al. 2006). Coupled with the selective pressures associated with aquaculture, this evolutionary capacity has most likely been responsible for the emergence of highly pathogenic VHSV isolates within the aquaculture industry. This is supported by increased rates of genetic evolution observed in VHSV isolates circulating in the aquaculture industry compared to those recovered from endemic marine reservoirs (Einer-Jensen et al. 2004).

Despite recovery of VHSV isolates from around the British Isles, until relatively recently the UK remained free of the disease. Outbreaks in turbot farms in Ireland and Scotland did, however, highlight the risk posed to this species, which has since been shown to be susceptible to naturally occurring viral isolates (Snow et al. 2005). These disease episodes highlighted the real risk of importing VHSV into cage-based aquaculture systems established in areas where the virus is known to be endemic. VHS is a List II disease, according to the current European Health Council Directive 91/67/EEC, and detection of the agent in aquaculture requires an eradication strategy to maintain freedom from the disease. The consequences of this were recently illustrated following the first identification of VHSV in rainbow trout in England in 2006 (OIE 2006a).

Since VHSV is endemic in wild fish and its detection in aquaculture has serious consequences, the present study was undertaken to determine the potential distribution of VHSV in sea cagebased salmonid aquaculture farms in Scotland. Such aquaculture may pose a risk factor for the emergence of VHS in the UK, especially when it is considered that VHSV has been detected in both marine rainbow trout and Atlantic salmon (Skall et al. 2005).

A highly sensitive quantitative realtime RT-PCR (qRT-PCR) was developed, which targeted a conserved region of the nucleoprotein $(\mathrm{N})$ gene and was demonstrated to be capable of detecting all known European isolates of the virus. An endogenous control, specific to the species examined, was employed to ensure sample integrity. In addition, a novel positive control strategy was developed with the capacity to differentiate the positive control from true VHSV-derived positive results. This highly sensitive and specific assay was used as a basis for an anonymous screening programme of farmed rainbow trout and Atlantic salmon held in sea cages in Scottish marine waters.

\section{MATERIALS AND METHODS}

Development of a highly sensitive and specific qRTPCR method. In order to design an assay capable of detecting all known European genotypes of VHSV, we selected a region of the conserved $\mathrm{N}$ gene, extensively characterized by Snow et al. (2004). A multiple sequence alignment including all publicly available and relevant sequence information (detailed in Table 1) was performed using ClustalW (Fig. 1). Primers were designed using the Primer Express software (Applied Biosystems). The primer set selected was capable of amplifying a $109 \mathrm{bp}$ fragment of the $\mathrm{N}$ gene (universal VHSV forward 5'-TGT CCG TGC TTC TCT CCT ATG TAC T-3' and universal VHSV reverse $5^{\prime}$-GCC CTG ACT GCC TGT GTC A-3'). A universal probe situated within this $109 \mathrm{bp}$ amplicon and designed to be capable of detecting European Genotypes I to III (universal VHSV 6-FAM-CTC ACA GAC ATG GG-MGB) was obtained (Taqman ${ }^{\circledR}$ MGB, Applied Biosystems).

Table 1. Viral haemorrhagic septicaemia virus (VHSV) strain isolations used in validation of the universal VHSV quantitative real-time PCR (qRT-PCR) assay specificity. Isolates in bold were used for validation of the universal VHSV qRT-PCR efficiency and sensitivity. DFVF: Danish Institute for Food and Veterinary Research

\begin{tabular}{|llll|}
\hline $\begin{array}{l}\text { VHSV } \\
\text { genotype }\end{array}$ & Isolate number & $\begin{array}{c}\text { Accession } \\
\text { number }\end{array}$ & \\
\hline Ia & DK-F1 & AY356633 & Jensen (1965) \\
& DK-3345 & AY356639 & DFVF (unpubl.) \\
& DK-5133 & AY356642 & DFVF (unpubl.) \\
& FR-07/71 & AJ233396 & Le Berre et al. (1977) \\
Ib & DK-1p40 & AJ130919 & Mortensen et al. (1999) \\
& DK-1p3 & AY356651 & Mortensen et al. (1999) \\
& DK-MRhabdo & AY356632 & Jensen et al. (1979) \\
II & DK-1p49 & AY356743 & Mortensen et al. (1999) \\
& DK-5p551 & AY356690 & H. F. Skall et al. (unpubl.) \\
III & UK-MLA98/6PT10 & AY356723 & King et al. (2001) \\
& UK-MLA98/4CO1 & AY356735 & King et al. (2001) \\
& UK-MLA98/6WH1 & AY356729 & King et al. (2001) \\
& UK-MLA98/6PT14 & AY356730 & King et al. (2001) \\
& DK-2p51 & AJ130917 & Mortensen et al. (1999) \\
& DK-4p101 & AJ130918 & Mortensen et al. (1999) \\
\hline
\end{tabular}



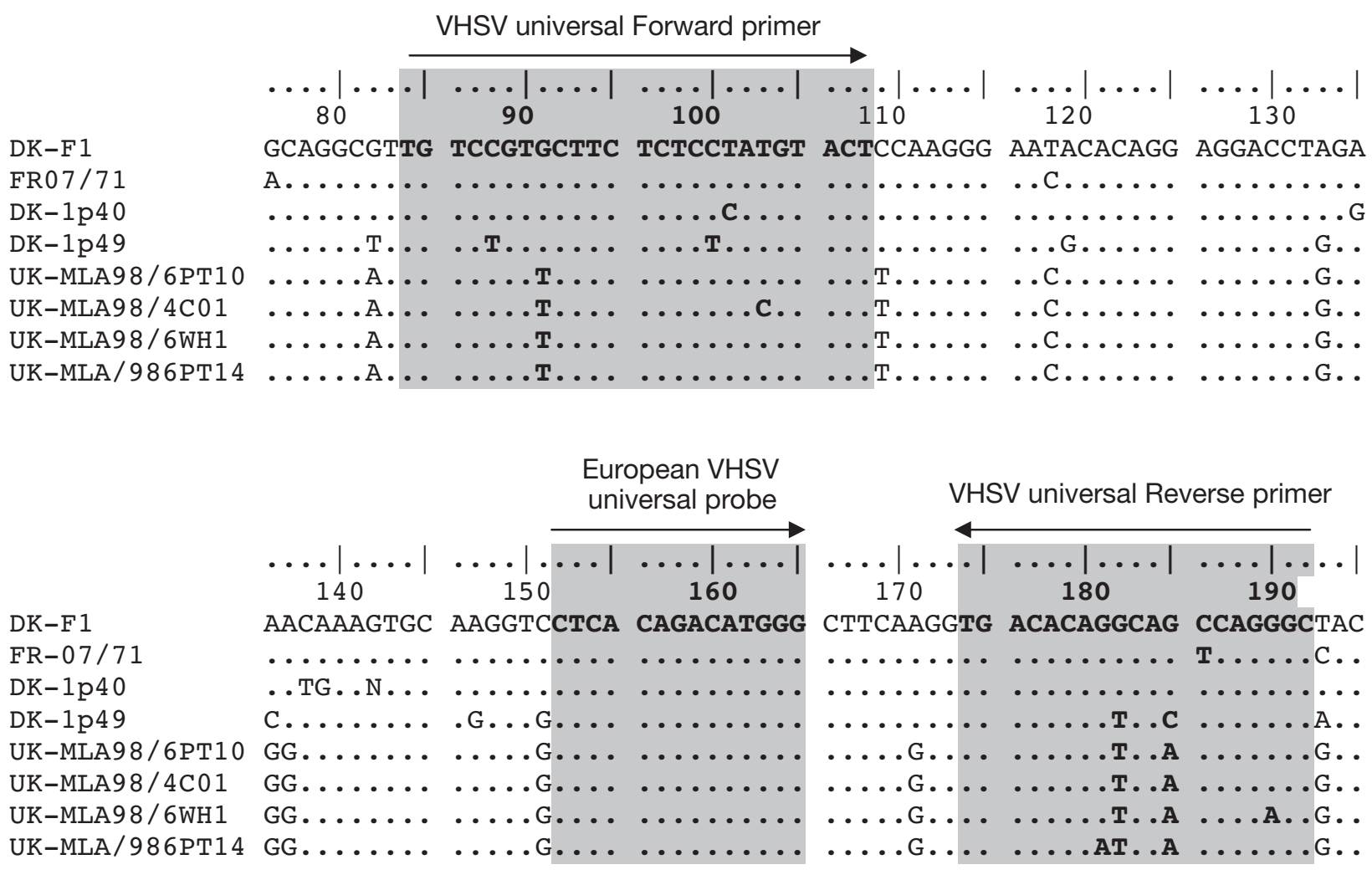

Fig. 1. Partial nucleoprotein (N-gene) alignment of the European viral haemorrhagic septicaemia virus (VHSV) Genotypes I, II and III. See Table 1 for accession numbers

Endogenous control assay design. In order to provide an endogenous control for the universal European VHSV qRT-PCR, primers and a probe for detection of the salmon elongation factor $1 \alpha$ gene (sELF-1 $\alpha$ ) were used (see Snow et al. 2006). This endogenous control assay is specific to cDNA derived from mRNA since the probe is located across a splicing site. Due to conservation in gene structure and sequence, the assay is also capable of amplification of the ELF-1 $\alpha$ gene of rainbow trout.

Exogenous positive control assay design. A standard pUC57 plasmid containing a VHSV positive control insert of $195 \mathrm{bp}$ was manufactured by GeneCust (www.genecust.com) (Fig. 2). The control insert was based on the sequence of VHSV isolate FR-07/71 (GenBank accession number AJ233396) and thus included the universal European VHSV primer- and probe-binding sequences described in Table 1. This exogenous control is used in positive control reactions to verify the capability of each assay to amplify its target. In order to allow differentiation of the positive control material from positive field samples, an additional probe target sequence was included in the template (Fig. 2). Using a second probe targeting this sequence, labelled with a different fluorophore (VIC-ACC GTC
TAG CAT CCA GT-MGB) in all test reactions, enables cross-contamination with the exogenous positive control template to be identified readily.

Generation of exogenous positive control RNA template. A pUC57 plasmid with the VHSV positive control insert was used to transform DH5 $\alpha$ competent cells following the Rapid One Shot Chemical Transformation protocol (Invitrogen). A single bacterial colony was transferred into $10 \mathrm{ml}$ Luria-Bertani (LB) Broth (Sigma) with ampicillin (Sigma), incubated on a shaking platform for $8 \mathrm{~h}$ at $37^{\circ} \mathrm{C}$, then transferred into $140 \mathrm{ml} \mathrm{LB}$ Broth with ampicillin and grown overnight at the same temperature. VHSV positive control plasmid DNA was purified and precipitated using an EndoFree Plasmid Maxi kit (Qiagen). Approximately $15 \mu \mathrm{g}$ of plasmid DNA was linearized prior to in vitro transcription using the SpeI restriction enzyme (New England Biolabs) in a $50 \mu$ reaction. Linearized exogenous positive control DNA was purified using the Wizard DNA Clean-Up system (Promega) and quantified on a $2 \%$ agarose gel using a DNA Mass Ladder (Invitrogen) and ethidium bromide staining (Sigma).

Approximately $10 \mu \mathrm{g}$ linear positive control DNA was used in a $100 \mu \mathrm{l}$ in vitro transcription reaction containing $1 \times \mathrm{T} 7$ transcription buffer, $100 \mathrm{mM}$ rNTPs 
GGACCCCAGACTGTCCATGGTAATACGACTCACTATA\#GGGCG AACAGGCGTTGTCCGTGCTTCTCTCCTATGTACTCCAAGGGAA CACACACCGTCTAGCATCCAGTAGGAGGACCTAGAAACAAAG TGCAAGGTCCTCACAGACATGGGCTTCAAGGTGACACAGGCA GTCAGGGCCACGAGCATACTAGTATC

Fig. 2. Sequence from the exogenous positive control plasmid. SpeI restriction site in bold and italics; universal viral haemorrhagic septicaemia virus (VHSV) quantitative real-time RTPCR (qRT-PCR) primers underlined; universal VHSV qRTPCR probe in bold, underlined; artificial positive control probe sequence in italics, underlined. \#: transcription start

(25 mM ATP, CTP, GTP, UTP) and $10 \mu \mathrm{l}$ T7 enzyme mix (RNA polymerase, recombinant RNasin ${ }^{\circledR}$ ribonuclease inhibitor and recombinant inorganic pyrophosphatase) (RiboMAX $^{\mathrm{TM}}$ Large Scale RNA Production System, Promega). The RNA transcript was DNase-treated, phenol-chloroform-extracted, and ethanol-precipitated according to the manufacturer's instructions. An in vitro transcription positive control reaction using a luciferase gene under the control of the T7 RNA polymerase promoter as template was set up in total volume of $20 \mu \mathrm{l}$ according to the manufacturer's instructions. The resultant positive control RNA transcript was diluted 1:10 with RNase/DNase free water (Sigma) and aliquots stored at $-80^{\circ} \mathrm{C}$.

Field collection of samples for VHSV survey. Anonymously, within 4 regions of Scotland (mainlandnorth, mainland-south, Western Isles, Orkneys and Shetland), 68 sites were selected for screening farmed Atlantic salmon Salmo salar and 5 sites for rainbow trout Oncorhynchus mykiss. Head kidney (approx. $100 \mathrm{mg}$ ) was collected from 30 fish on each site. Samples were pooled in 6 pools $(\mathrm{a}-\mathrm{f})$, each containing material from 5 fish. Samples were collected in RNAlater (Ambion) and coded to ensure that they could only be identified to broad geographic areas and not individual farm sites.

RNA extraction and RT-PCR. To facilitate assay validation, selected VHSV isolates (Table 1) were propagated in BF-2 cell cultures and RNA was extracted using TRIZOL as described by Snow et al. (2004). For processing purposes of aquaculture samples, kidney pools a-f were combined into 3 pools, each containing approximately $3 \mathrm{mg}$ of head kidney from each of 10 fish. Head kidneys were homogenised in $600 \mu \mathrm{l}$ of Buffer RLT (Qiagen) for $1 \mathrm{~min}$ at $30 \mathrm{~Hz}$ using the TissueLyser system (Qiagen). Three subsequent total RNA extractions were performed per site using the RNeasy Mini kit according to the manufacturer's protocol for the extraction of RNA from animal tissues (Qiagen). Total RNA was finally suspended in $200 \mu \mathrm{l}$ molecular grade water (Sigma) and stored at $-80^{\circ} \mathrm{C}$. Negative extraction controls (designated A controls) were conducted by performing blank extractions. Con- trols were taken through subsequent RT-PCR and qRT-PCR steps.

For VHSV cell culture isolates, reverse transcription (RT) reactions were conducted according to Snow et al. (2006). Reverse transcription of the aquaculture samples was performed using the Taqman ${ }^{\circledR}$ reverse transcription reagent kit (Applied Biosystems) in a final volume of $25 \mu \mathrm{l}$. Two $\mu \mathrm{l}$ of total RNA was mixed with $2.5 \mu \mathrm{M}$ random hexamers and reverse transcription master mix containing $1 \times \mathrm{RT}$ Buffer, $5.5 \mathrm{mM} \mathrm{MgCl}_{2}$, $2 \mathrm{mM}$ deoxyNTPs, $0.4 \mathrm{U}$ RNase inhibitor, $1.25 \mathrm{U}$ multiscribe reverse transcriptase and molecular grade water to final volume of $25 \mu$ l. The RT-PCRs were incubated at $25^{\circ} \mathrm{C}$ for $10 \mathrm{~min}, 48^{\circ} \mathrm{C}$ for $30 \mathrm{~min}$, and $95^{\circ} \mathrm{C}$ for $2 \mathrm{~min}$.

Exogenous positive control cDNA was synthesised from $1 \mu$ of diluted positive control RNA using the Taqman ${ }^{\circledR}$ reverse transcription reagent kit and conditions as described above. Negative RT-PCR controls were conducted by performing reactions containing no target (designated B control). Controls were taken through subsequent qRT-PCR steps.

qRT-PCR and cycling conditions. Assays were performed on an Applied Biosystems 7000 Sequence Detection System programmed to conduct the following cycling profile: $50^{\circ} \mathrm{C}$ for 2 min (AmpErase uracil $\mathrm{N}$-gycosylase incubation), $95^{\circ} \mathrm{C}$ for $10 \mathrm{~min}$ (AmpliTaq Gold polymerase activation) followed by 45 cycles of $95^{\circ} \mathrm{C}$ for $15 \mathrm{~s}$ (denaturation) and $60^{\circ} \mathrm{C}$ for $1 \mathrm{~min}$ (annealing/extension). Multiplex qRT-PCRs were conducted in a final volume of $20 \mu \mathrm{l}$ containing $1 \mu \mathrm{l}$ cDNA template, $1 \times$ Taqman ${ }^{\circledR}$ Universal PCR mastermix (Applied Biosystems), $900 \mathrm{nM}$ each primer and $250 \mathrm{nM}$ of each Taqman ${ }^{\circledR}$ probe (universal VHSV and exogenous positive control). The exogenous positive control reaction contained $1 \mu \mathrm{l}$ of exogenous positive control cDNA as a target. Three non-target controls (NTC controls) containing no template were performed along with each qRT-PCR assay. Concentrations of primers and probe were selected based on the previous validation study of Snow et al. (2006) based on the infectious salmon anaemia virus (ISAV) qRT-PCR assay. No loss in detection ability of the universal European VHSV qRT-PCR assay was recorded by reducing the total reaction volume to $20 \mu \mathrm{l}$ compared to $25 \mu \mathrm{l}$ used by Snow et al. (2006) (data not shown). ELF-1 $\alpha$ endogenous control assays were conducted separately for each salmon and trout sample.

Validation of universal European VHSV qRT-PCR efficiency. In order to obtain relative quantification of VHSV in the kidney samples analysed, reaction efficiencies of the universal European VHSV qRT-PCR assay were required. A 10-fold dilution series of cDNA was prepared for each of the VHSV isolates listed in Table 1, using a Liquid Handling Workstation epMotion 5070 (Eppendorf). The universal European VHSV 
assay was performed in triplicate for each dilution. Standard curves were generated by plotting the relative dilution of cDNA versus the cycle number required to elevate the fluorescence signal above the threshold for the universal European VHSV assay. The ratio of VHSV and sELF-1 $\alpha$ (Moore et al. 2005) converted to copy number equivalent (qt), calculated as $q t=10^{(b-\mathrm{Ct}) / a}$, where $a$ is the slope, $b$ is the intercept from a standard curve of each specific target gene and $\mathrm{Ct}$ is the threshold cycle, was used for relative quantification of VHSV in the kidney samples analysed.

Sensitivity of qRT-PCR and comparison with conventional RT-PCR. The same 10 -fold dilution series of the VHSV cDNA were used to compare the sensitivity of the Taqman ${ }^{\circledR}$ qRT-PCR method with that of conventional RT-PCR. Triplicate individual RT-PCRs were performed by using $5 \mu \mathrm{l}$ of cDNA and conditions identical to those described by Snow et al. (2004). We subjected $5 \mu \mathrm{l}$ of each amplified $\mathrm{N}$ gene PCR product to electrophoresis on a $1 \%$ ethidium bromide-stained agarose gel.

Specificity of qRT-PCR assay. For specificity testing of the universal European VHSV qRT-PCR assay, isolates of all 3 European VHSV Genotypes (I, II and III), including European VHSV isolates whose sequence exhibited differences in the primer binding sites were used as templates in the qRT-PCR (see Table 1).

Nucleotide sequences of primers and all 3 probes were compared to entries in GenBank using BLAST (blastn) (Altschul et al. 1990) in order to identify similarity to any known organisms to prevent potential cross-reactivity with a non-target template. The universal European VHSV assay was tested against cDNA derived from a range of other RNA viruses capable of infecting Atlantic salmon, including spring viraemia of carp virus (SVCV UKE117, SVCV UK980548), tench rhabdovirus (UK994591), grass carp rhabdovirus (GCR-V76), infectious haematopoietic necrosis virus (IHNV32-87), pike fry rhabdovirus (PFRV-F4) and perch rhabdovirus (PRV DK6389).

\section{RESULTS}

\section{Efficiency, detection end-point, and relative quantification parameters of qRT-PCR assay}

The universal European VHSV assay exhibited comparable efficiencies for all VHSV isolates tested, with a maximum difference in slope $(\Delta \mathrm{S})$ of 0.36 obtained between the isolates. Each reaction series also showed a high correlation between cycle number and dilution factor (Table 2).

Based on reproducible detection of VHSV at high dilutions, a cut-off point for the universal European
VHSV qRT-PCR assay was set up using all pathogen isolates tested as templates (see Table 3). An average $\mathrm{Ct}$ value from the last detectable dilution of VHSV in all triplicates was recorded as a cut-off point for the universal European VHSV qRT-PCR assay. The lowest cutoff point resulting from all pathogen isolates tested, $\mathrm{Ct}=34$, was considered as universal cut-off point for the validated assay.

\section{Sensitivity of qRT-PCR and comparison with conventional RT-PCR}

The universal European VHSV qRT-PCR assay consistently detected VHSV at much higher dilutions compared to the conventional RT-PCR for all VHSV isolates tested (Table 3). As for some VHSV isolates (DK-F1 and FR-07/71), the present assay was able to detect the pathogen target at a dilution $10^{3}$ greater than that detected by the conventional RT-PCR. Furthermore, very weak products were observed on agarose gels from higher dilutions nearing the endpoint of detection for conventional RT-PCR, which required experience in their interpretation.

\section{Specificity of qRT-PCR assay}

The ability of the universal European VHSV assay to detect virus target from different genotypes was tested. It was possible to detect accurately all isolates from European VHSV Genotypes I, II and III despite the presence of differences in nucleic acid sequences (see Fig. 1). The ability to detect VHSV target was not significantly affected by the presence of the exogenous positive control probe in the multiplex qRT-PCR (differences of 1 to 2 cycles between single/multiplex reactions).

No false positives were recorded when cDNA of other RNA viruses was used as template in the qRTPCR which suggests a high specificity.

Table 2. Reaction efficiency data of the universal viral haemorrhagic septicaemia virus (VHSV) quantitative real-time RT-PCR assay for all tested pathogen isolates

\begin{tabular}{|lcc|}
\hline VHSV isolate & Slope value & $\mathrm{R}^{2}$ \\
\hline FR-07/71 & -3.498013 & 0.998171 \\
DK-F1 & -3.303595 & 0.993958 \\
DK-1p40 & -3.439067 & 0.994642 \\
DK-1p49 & -3.245654 & 0.997252 \\
UK-MLA98/ 4CO1 & -3.574996 & 0.991144 \\
UK-MLA98/6PT10 & -3.217960 & 0.996797 \\
UK-MLA98/6WH1 & -3.235379 & 0.990060 \\
UK-MLA98/6PT14 & -3.314466 & 0.998785 \\
\hline
\end{tabular}




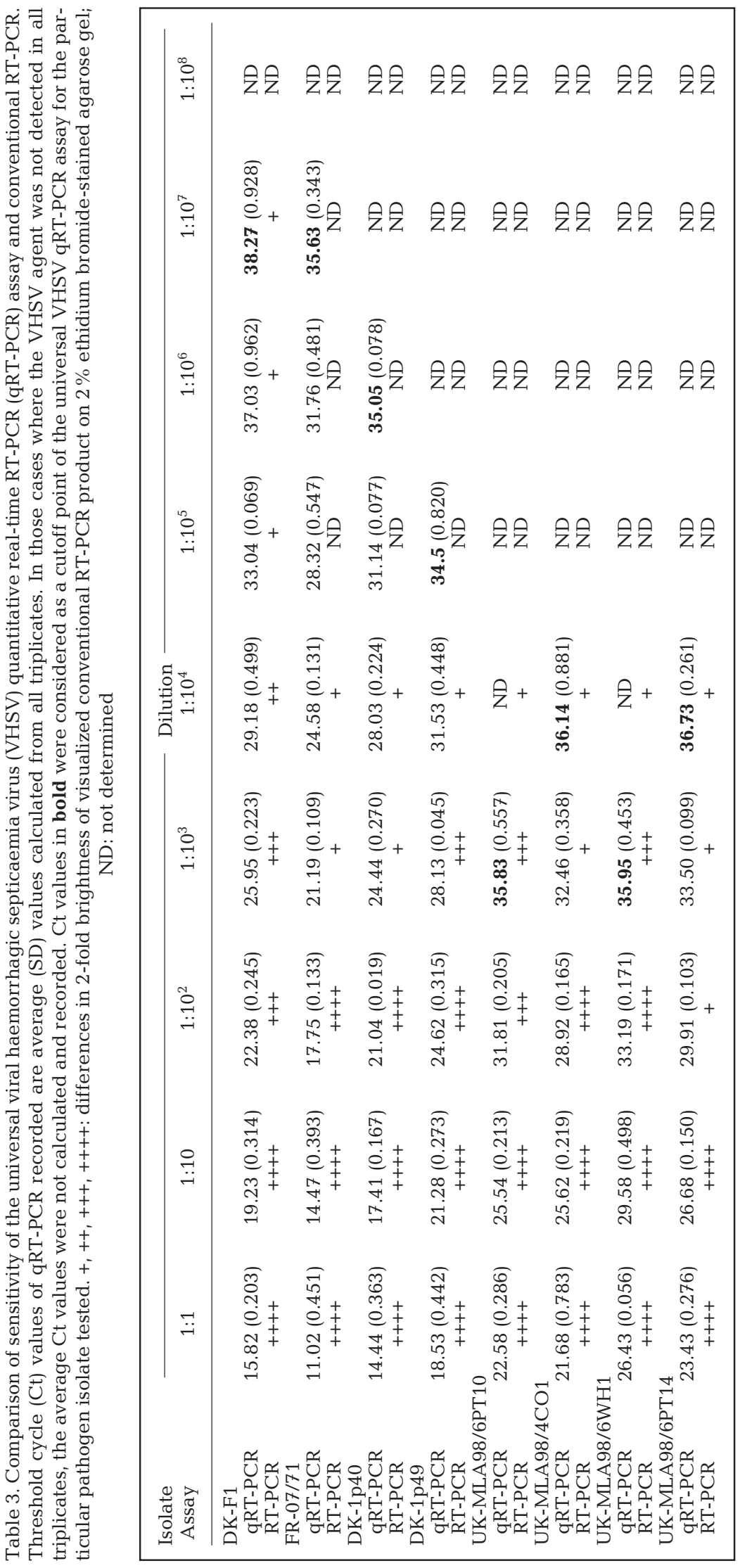

\section{Application of qRT-PCR assay to the detection of VHSV in field samples}

The universal European VHSV qRTPCR assay was selected as the more sensitive technique for detection of VHSV and was thus applied to screening aquaculture survey samples. In total, 2040 individuals of seawater Atlantic salmon and 150 individuals of seawater rainbow trout were included in the screening programme. cDNA derived from 3 subsamples of pooled kidney RNA per site were tested for the presence of the pathogen. The ELF-1 $\alpha$ assay was applied as an endogenous control, with all samples showing consistently high detection of this housekeeping gene, indicating the high quality of total RNA used for cDNA synthesis. However, no evidence was detected for the presence of VHSV in association with either marinefarmed Atlantic salmon or rainbow trout in Scotland.

\section{DISCUSSION}

Development of a rapid, accurate and sensitive molecular diagnostic tool is crucial for large-scale surveillance programmes for VHSV, for example, in disease outbreak situations or simply for routine diagnostic testing. The original application of the RT-PCR as a diagnostic tool for screening for VHSV provided a relatively rapid technique compared to the standard cell culture procedures (OIE 2006b). Two viral genes, the glycoprotein (G gene) and $\mathrm{N}$ gene have been the most common targets of conventional RT-PCR assays for detection of various rhabdoviruses in fish (e.g. Bruchhof et al. 1995, Miller et al. 1998, Snow et al. 2004, Lopez-Vazquez et al. 2006a). Due to increased demand for the development of more sensitive diagnostic methods, qRTPCR has recently been developed, representing a powerful technique capable of rapidly generating accurate and reproducible results. The qRT-PCR reduces risk of cross-contamination with nontarget DNA and provides an opportunity for automation of both results generation and data processing. 
The primers and Taqman ${ }^{\circledR}$ probe of the qRT-PCR assay described in this study target the $\mathrm{N}$ gene of VHSV. This gene was chosen over the $\mathrm{G}$ gene because it is known that the $\mathrm{N}$ gene is relatively more abundant than $\mathrm{G}$ gene due to the characteristic transcriptional attenuation of rhabdoviruses (Rose \& Schubert 1987). Moreover, it has been previously shown that the $\mathrm{N}$ gene qRT-PCR is more efficient and sensitive than assays targeting the G gene of VHSV (Chico et al. 2006). In the present study, sensitivity of the VHSV qRT-PCR was compared to a conventional $\mathrm{N}$ gene RT-PCR (Snow et al. 2004). Increased sensitivity of qRT-PCR was exhibited for all VHSV isolate cDNAs used as template. In some cases, the qRT-PCR approach was able to detect VHSV (DK-F1 and FR-07/71) at a dilution $10^{3}$ times greater than that detected by the conventional RT-PCR. On the other hand, sensitivity of detection of some UK isolates appeared to be more or less comparable using both assays based on the data summarised in Table 3. However, RT-PCR products from the higher dilutions were in some cases very faint, making interpretation of results extremely difficult. In the case of the qRT-PCR assay, the pathogen target was correctly detected in these higher dilutions (for all triplicates), showing still relatively low $\mathrm{Ct}$ values. As the presented qRT-PCR assay was designed to be used as a possible diagnostic tool, reliability and simple, quick interpretation of results are important. A similar comparison was performed when validating a qRT-PCR assay for detection of ISAV (Snow et al. 2006). Improved sensitivity of the qRT-PCR approach for detection of the ISAV was demonstrated during routine diagnostic surveillance of Scottish aquaculture salmon during 2004, revealing a greater number of true positive samples than the conventional RT-PCR.

In addition to sensitivity, further emphasis was placed on reproducibility and reliability of the diagnostic qRTPCR developed in this study. An exogenous positive control plasmid containing a partial sequence of VHSV isolate FR-07/71 and including an additional artificial probe target sequence was commercially constructed. Control RNA transcript was synthesized by in vitro transcription and served as a positive template for RTPCR synthesis and subsequent VHSV qRT-PCR. There are several advantages of this approach compared with using diluted VHSV plasmids or previously identified positive field samples. Using an additional Taqman ${ }^{\circledR}$ probe with a different fluorophore targeting artificial sequences inserted in control plasmid, it is possible not only to rule out contamination with the exogenous positive control plasmid from a true VHSV positive, but also to distinguish a true VHSV negative from a failed assay. Moreover, the ability to recognize the artificial positive plasmid in the case of contamination helps to prevent the need for sequencing, which is a time-con- suming and expensive way to identify a true positive. Thus, the multiplex VHSV qRT-PCR assay represents a sensitive and extremely reliable approach for diagnostic testing compared to the conventional RT-PCR.

The present qRT-PCR assay was validated as a robust and universal assay for detection of European VHSV RNA in fish tissues. All European VHSV isolates characterised to date, exhibiting differences in nucleic acid sequences in the priming sites compared to isolate FR-07/71, were shown to be detectable.

To comply with the EC Directive 91/67/EEC in Scotland, aquaculture farms are inspected annually and tested for the List 2 disease VHS every 2 years using the standard screening method approved by the World Organization for Animal Heath (OIE 2006b) based on the isolation of VHSV in cell culture. Since 1998, in Scotland 1978 sites have been visited and samples (30 fish in 6 pools of 5 individuals) for VHSV testing were taken. So far, all samples collected have tested negative for the presence of the VHSV. The present marine aquaculture survey of Atlantic salmon and rainbow trout confirmed previous findings and revealed no positives using the sensitive universal European VHSV qRT-PCR approach. This indicated the absence, or potentially very low prevalence, of this disease in Scottish marine-cultured Atlantic salmon and rainbow trout.

For Atlantic salmon, this finding was perhaps not surprising since, in Europe, the detection of VHSV in this species is very rare, including only a single isolation of virus in Spain (Jimenez de la Fuente et al. 1988), which was further characterized by Lopez-Vazquez et al. (2006b). In addition, results of experimental infection trials using bath immersion showed that all types of VHSV are non- or lowly pathogenic to Atlantic salmon (Skall et al. 2005). Infection trials were also conducted for rainbow trout, and several marine North European and North American VHSV isolates exhibited no or low/medium pathogenicity to this species in both water-borne infection and by intraperitoneal injection (Skall et al. 2005). Nevertheless, both seawater Atlantic salmon and rainbow trout are still considered possible carriers of VHSV and a potential threat to the introduction of VHSV to the freshwater environment. Therefore, a need remains for future surveillance of these species in marine environment.

Acknowledgements. We thank the managers of the Scottish marine cage-based salmonid farms for participation in the present survey. We also thank the staff of Fish Health Inspectorate, FRS Marine Laboratory, Aberdeen, Scotland, for collection of the kidney samples; the staff of the Virology Group, FRS Marine Laboratory, for providing virus cell cultures; and Dr. A. Gregory, Epidemiology Group, FRS Marine Laboratory, for providing information on the testing programme in marine salmonid farms in Scotland. 


\section{LITERATURE CITED}

Altschul SF, Gish W, Miller W, Myers EW, Lipman DJ (1990) Basic local alignment search tool. J Mol Biol 215: 403-410

Bruchhof B, Marquardt O, Enzmann PJ (1995) Differential diagnosis of fish pathogenic rhabdoviruses by reverse transcriptase-dependent polymerase chain reaction. J Virol Methods 55:111-119

Chico V, Gomez N, Estepa A, Perez L (2006) Rapid detection and quantification of viral hemorrhagic septicemia virus in experimentally challenged rainbow trout by real-time RTPCR. J Virol Methods 132:154-159

Einer-Jensen K, Ahrens P, Forsberg R, Lorenzen N (2004) Evolution of the fish rhabdovirus viral haemorrhagic septicaemia virus. J Gen Virol 85:1167-1179

Einer-Jensen K, Winton J, Lorenzen N (2005) Genotyping of the fish rhabdovirus, viral haemorrhagic septicaemia virus, by restriction fragment length polymorphisms. Vet Microbiol 106:167-178

Elsayed E, Faisal M, Thomas M, Whelan G, Batts W, Winton J (2006) Isolation of viral haemorrhagic septicaemia virus from muskellunge, Esox masquinongy (Mitchill), in Lake St Clair, Michigan, USA reveals a new sublineage of the North American genotype. J Fish Dis 29:611-619

Jensen MH (1965) Research on the virus of Egtved disease. Ann NY Acad Sci 126:422-426

Jensen NJ, Bloch B, Larsen JL (1979) The ulcus-syndrome in cod (Gadus morhua) III. A preliminary virological report. Nord Vet-Med 31:436-442

Jimenez de la Fuente J, Marcotegui MA, San Juan ML, Basurco B (1988) Diagnosis of viral diseases in salmonid farms in Spain. Bull Eur Assoc Fish Pathol 8:1-2

King JA, Snow M, Smail DA, Raynard RS (2001) Distribution of viral haemorrhagic septicaemia virus in wild fish species of the North Sea, north east Atlantic Ocean and Irish Sea. Dis Aquat Org 47:81-86

Knipe DM, Howley PM, Griffin DE, Lamb RA (2006) Fields virology, 5th edn. Lippincott Williams \& Wilkins, Philadelphia, PA

Le Berre M, de Kindelin P, Metzger A (1977) Identification serologique des rhabdovirus des salmonids. Bull Off Int Epizoot 87:391-393

Lopez-Vazquez C, Dopazo CP, Olveira JG, Barja JL, Bandin I (2006a) Development of a rapid, sensitive and non-lethal diagnostic assay for the detection of viral haemorrhagic septicaemia virus. J Virol Methods 133:167-174

Lopez-Vazquez C, Raynard RS, Bain N, Snow M, Bandin I, Dopazo CP (2006b) Genotyping of marine viral haemorrhagic septicaemia virus isolated from the Flemish Cap by nucleotide sequence analysis and restriction fragment length polymorphism pattern. Dis Aquat Org 73: $23-31$

Editorial responsibility: Mark Crane, Geelong, Victoria, Australia
Miller TA, Rapp J, Wastlhuber U, Hoffmann RW, Enzmann PJ (1998) Rapid and sensitive reverse transcriptasepolymerase chain reaction based detection and differential diagnosis of fish pathogenic rhabdoviruses in organ samples and cultured cells. Dis Aquat Org 34:13-20

Moore LJ, Somamoto T, Lie KK, Dijkstra JM, Hordvik I (2005) Characterisation of salmon and trout $\mathrm{CD} 8 \alpha$ and $\mathrm{CD} 8 \beta$. Mol Immunol 42:1225-1234

> Mortensen HF, Heuer OE, Lorenzen N, Otte L, Olesen NJ (1999) Isolation of viral haemorrhagic septicaemia virus (VHSV) from wild marine fish species in the Baltic sea, Kattegat, Skagerrak and the North Sea. Virus Res 63: 95-106

> Nishizawa $T$, Iida $H$, Takano $R$, Isskihi $T$, Nakajima $K$, Muroga K (2002) Genetic relatedness among Japanese, American and European isolates of viral hemorrhagic septicaemia virus (VHSV) based on partial G and P genes. Dis Aquat Org 48:143-148

Office International des Epizooties (OIE) (2006a) Viral haemorrhagic septicaemia in the United Kingdom/Great Britain. Dis Info 19:22. Available at: www.oie.int/eng/info/ hebdo/AIS_13.htm

Office International des Epizooties (OIE) (2006b) Manual of diagnostic tests for aquatic animals. OIE, Paris

Rose J, Schubert M (1987) Rhabdovirus genomes and their products. In: Wagner RR (ed) The rhabdoviruses. Plenum Press, New York, p 129-159

Schäperclaus W (1938) Die Schädigungen der deutschen Fischerei durch Fischparasiten und Fischkrankheiten. Allg Fisch-Ztg 41:256-270

Skall HF, Slierendrecht WJ, King JA, Olsen NJ (2004) Experimental infection of rainbow trout Oncorhynchus mykiss with viral haemorrhagic septicaemia virus isolates from European marine and farmed fishes. Dis Aquat Org 58: 99-110

Skall HF, Olesen NJ, Mellergaard S (2005) Viral haemorrhagic septicaemia virus in marine fish and its implications for fish farming - a review. J Fish Dis 28:509-529

Snow M, Cunningham CO, Melvin WT, Kurath G (1999) Analysis of the nucleoprotein gene identifies distinct lineages of viral haemorrhagic septicaemia virus within the European marine environment. Virus Res 63:35-44

Snow M, Bain N, Black J, Taupin V and others (2004) Genetic population structure of marine viral haemorrhagic septicaemia virus (VHSV). Dis Aquat Org 61:11-21

Snow M, King JA, Garden A, Shanks AM, Raynard RS (2005) Comparative susceptibility of turbot Scophthalmus maximus to different genotypes of viral haemorrhagic septicaemia virus. Dis Aquat Org 67:31-38

Snow M, McKay P, McBeath AJA, Black J and others (2006) Development, application and validation of a Taqman real-time RT-PCR assay for the detection of infectious salmon anaemia virus (ISAV) in Atlantic salmon (Salmo salar). Dev Biol 126:133-145

Submitted: April 13, 2007; Accepted: March 3, 2008 Proofs received from author(s): June 16, 2008 